\title{
Simultaneous determinations of uterine blood flow and plasma concentrations of placental lactogen in late- pregnant goats
}

\author{
T. J. Hayden*, H. L. Buttle, P. L. Rees, Susan V. Smith and \\ Isabel A. Forsyth
}

Department of Physiology, National Institute for Research in Dairying, Shinfield, Reading RG2 9AT, Berks, U.K.

\begin{abstract}
Summary. Blood flow in the middle uterine artery was measured with electromagnetic blood flow probes, and placental lactogen in jugular and uterine venous plasma was estimated as total lactogenic activity using a radioreceptor assay. There was no circadian variation in uterine arterial blood flow in late pregnancy (Days 105124) and the pattern of blood flow varied between goats. Blood flow was quite stable for periods of up to $40 \mathrm{~min}$ although at other times a rapid fall (by up to $90 \%$ ) was followed by a gradual recovery. These spontaneous changes lasting up to $30 \mathrm{~min}$ could not be consistently related to postural or behavioural changes. Acute decreases of about the same duration could also be induced by administration of adrenaline. In the short-term there was no association between uterine blood flow and total lactogenic activity in the peripheral circulation during spontaneous or adrenaline-induced depression of blood flow. More limited short-term observations on total lactogenic activity in the uterine vein also failed to show a relationship with blood flow in the uterine artery.
\end{abstract}

\section{Introduction}

The concentration of placental lactogen in the plasma of pregnant sheep and goats is related to the stage of gestation (Buttle, Forsyth \& Knaggs, 1972; Kelly, Robertson \& Friesen, 1974; Djiane \& Kann, 1975; Handwerger et al., 1977; Currie, Kelly, Friesen \& Thorburn, 1977; Chan, Robertson \& Friesen, 1978; Hayden, Thomas, Smith \& Forsyth, 1980) and number of fetuses (Gluckman, Kaplan, Rudolph \& Grumbach, 1979; Hayden et al., 1980). Nevertheless, the regulation of placental lactogen secretion in ruminants is not well understood. In the sheep, arginine (Handwerger et al., 1978) and ornithine are potent stimuli to the secretion of placental lactogen into the maternal circulation (Handwerger, Grandis, Barry \& Crenshaw, 1981; Grandis \& Handwerger, 1983 ) although the mechanism is unknown. A dopaminergic mechanism may also be involved since bromocriptine transiently increased the amount of hormone in the placenta of sheep (Martal \& Lacroix, 1978) and depressed placental lactogen in plasma of sheep (Lowe et al., 1979) and goats (Buttle, Cowie, Jones \& Turvey, 1979).

Sequential measurement of placental lactogen in peripheral plasma has revealed spontaneous short-term fluctuations of the concentration of hormone. In the sheep concentrations vary by up to 2-fold from hour to hour (Taylor et al., 1980), while in the goat placental lactogen may vary by up to 3-fold hourly (Hayden et al., 1980). There was no evidence of a circadian rhythm in either study.

* Present address: Department of Zoology, University College Dublin, Belfield, Dublin, 4, Ireland. 
There are also spontaneous fluctuations of the concentration of placental lactogen in human plasma, presumed to be caused by changes in placental blood flow (Vigneri et al., 1975; Chard, 1981) since constriction of the maternal aorta or ligation of placental blood vessels reduces both placental blood flow and concentration of placental lactogen in the circulation of the rhesus monkey (Belanger, Shome, Friesen \& Myers, 1971). We have examined the relationship between blood flow in the uterine artery and total lactogenic activity, mainly due to placental lactogen, in the uterine and peripheral plasma of the pregnant goat.

\section{Materials and Methods}

\section{Animals}

Three pedigree British Saanen goats were used. They were housed during the study in individual stalls and were fed concentrates twice daily. Hay and water were available ad libitum. Surgery was performed between Days 101 and 107 of pregnancy. Electromagnetic perivascular flow sensors ( 4 or $5 \mathrm{~mm}$ i.d.; Skalar, Delft, The Netherlands) were applied to the main trunk of one (Goats 123 and 776) or both (Goat 851) middle uterine arteries. The flow sensors were connected to a flow meter unit (SEM 275; SE Laboratories Engineering Ltd, Feltham, Middlesex, U.K.) and the zero flow reading was set at the time of surgery by manual occlusion of the uterine arteries. Polyvinyl cannulae ( $1.9 \mathrm{~mm}$ o.d., $1.4 \mathrm{~mm}$ i.d.) were inserted into the corresponding uterine veins so that the tip lay approximately mid-way between the junction of the ovarian vein and the opening of the utero-ovarian vein into the vena cava. The leads and the cannulae were exteriorized through stab incisions in the flank. The goats were allowed at least 7 days to recover from surgery before measurements were taken. On the day before continuous recording of blood flow began a polyvinyl cannula was inserted into one jugular vein of each goat such that the tip lay close to the heart. Uterine blood flow was measured continuously and samples of uterine vein plasma were taken at least twice hourly for $24 \mathrm{~h}$ beginning between $09: 00$ and 10:00 h. One such recording was taken for Goats 776 and 851 , and three for Goat 123 . The behaviour of the goats was noted while recordings of blood flow were being made. The relationship between hormone concentration in jugular venous plasma and short-term fluctuations in uterine blood flow was studied by taking samples of blood at 5-10 min intervals over a 2 -h period while blood flow was continuously recorded. In all, twentythree $2-h$ periods were thus studied, 7 in Goat 123,8 in Goat 776 and 8 in Goat 851 . During 8 of these periods, while the uterine venous cannula was still patent, samples of uterine venous blood were collected simultaneously with the jugular blood. Three such collections were made from Goat 123, 2 from Goat 776 and 3 from Goat 851 . Blood samples $(3-5 \mathrm{ml})$ were collected into $10-\mathrm{ml}$ polystyrene centrifuge tubes containing heparin, chilled and centrifuged $(900 \mathrm{~g}, 20 \mathrm{~min})$. The plasma was stored without addition of preservative at $-20^{\circ} \mathrm{C}$ and was assayed within 3 weeks of collection. Cannulae were kept patent between samplings by filling with $0.9 \%(\mathrm{w} / \mathrm{v}) \mathrm{NaCl}$ containing 10 units heparin $\mathrm{ml}^{-1}$. At the end of the experimental period, adrenaline $(25-100 \mu \mathrm{g}$ in 2 $\mathrm{ml} ; 0 \cdot 6-1.35 \mu \mathrm{g} / \mathrm{kg}$ body weight) was injected into the jugular vein to reduce uterine blood flow and blood samples were taken from the jugular vein for estimations of placental lactogen.

The goats were killed 9-24 days after surgery. At autopsy, the wet weight of the placentomes dissected free of fetal membranes was recorded and the uterine artery, together with the attached perivascular flow sensor was removed. The flow meter was then calibrated by pumping $0.9 \%(w / v)$ $\mathrm{NaCl}$ through the artery at rates between 0 and $600 \mathrm{ml} / \mathrm{min}$. The meter response increased linearly with flow rate over this range $(r=0.994-0.998, n=12-18)$.

\section{Assay of placental lactogen}

Basal prolactin concentrations in the plasma of goats pregnant during winter in the northern hemisphere are low and represent less than $5 \%$ of the total lactogenic activity in plasma (Hayden $e t$ 
al., 1980). Accordingly total lactogenic activity, i.e. prolactin plus placental lactogen, in plasma was measured by radioreceptor assay as previously described (Hayden et al., 1980). The assay procedure employed rabbit liver membranes (Parke \& Forsyth, 1975) which had been freeze dried in the presence of $25 \mathrm{~mm}$-Tris- $\mathrm{HCl}, 10 \mathrm{mM}-\mathrm{CaCl}_{2}, \mathrm{pH} 7 \cdot 6$. Assay tubes contained $1 \mathrm{mg}$ membranes in 100 $\mu \mathrm{l}$ assay buffer ( $25 \mathrm{~mm}-\mathrm{Tris}-\mathrm{HCl}, 10 \mathrm{mM}-\mathrm{CaCl}_{2}, 0 \cdot 1 \% \mathrm{BSA}$ containing 100 units heparin/ml, $\mathrm{pH}$ 7.6), 25000 counts ${ }^{125}$ I-labelled ovine prolactin $(0.4 \mathrm{ng}$; NIH-P-S6, $25 \mathrm{i} . \mathrm{u} . / \mathrm{mg})$ in $100 \mu \mathrm{l}$ assay buffer, and either samples or standards in $100 \mu \mathrm{l}$. Plasma samples were assayed at $1: 5$ or $1: 10$ dilutions. The standard was ovine prolactin, NIH-P-S12, 35 i.u./mg, 0-2000 ng/tube, in a $1: 5$ or 1:10 dilution of plasma from an hypophysectomized, non-pregnant female goat. Tubes were incubated for $17 \mathrm{~h}$ at $4^{\circ} \mathrm{C}$. Ice-cold assay buffer $(2000 \mu \mathrm{l})$ was then added to each tube and the membranes were sedimented at $1500 \mathrm{~g}$ for $20 \mathrm{~min}$. The supernatant fraction was aspirated and the pellets were assayed for radioactivity. The results are expressed as ng equivalents of ovine prolactin per $\mathrm{ml}$ plasma. The sensitivity of the assay, calculated as the lowest concentration of prolactin-like activity differing from replicate determination of zero by two standard deviations, varied between 0.8 and $1.3 \mathrm{ng} / \mathrm{ml}$. Within-assay variation, assessed as standard deviations from differences between duplicates, was $4.82 \pm 0.28$ (s.e.m. $) \%(n=5)$. Within-assay variation, assessed as the coefficient of variation of replicate determinations on a quality control plasma, varied from 8.4 to $11.3 \%$. Interassay variation, assessed as the coefficient of variation of determinations of two quality control plasmas, ranged from 10.9 to $17 \cdot 3 \%$.

\section{Results}

Surgery had a variable effect on total lactogenic activity in plasma. Preoperative concentrations (mean \pm s.e.m.) of total lactogenic activity in jugular venous plasma were $635 \pm 46.3 \mathrm{ng} / \mathrm{ml}(n=$ 4), $315 \cdot 1 \pm 42.6 \mathrm{ng} / \mathrm{ml}(n=4)$ and $333.7 \pm 36.8 \mathrm{ng} / \mathrm{ml}(n=4)$ in Goats 123,776 and 851 respectively. At 1 day after operation total lactogenic activity in plasma was $696.2 \pm 38.6 \mathrm{ng} / \mathrm{ml}$ ( $n$ $=4$, N.S. $), 47.9 \pm 3.4 \mathrm{ng} / \mathrm{ml}(n=4, P<0.001)$ and $313.7 \pm 50.6 \mathrm{ng} / \mathrm{ml}(n=4$, N.S. $)$. By Day 7 , however, total lactogenic activity in plasma had recovered to $280.6 \pm 17.9 \mathrm{ng} / \mathrm{ml}(n=4)$ in Goat 776. There was little change in average blood flow during the post-operative period. Observations were made daily for at least $20 \mathrm{~min}$. The means of these daily blood flows were $215.7 \mathrm{ml} / \mathrm{min}$ (coefficient of variation, CV, 32\%) over 13 days after surgery in Goat 123, $197.5 \mathrm{ml} / \mathrm{min}(\mathrm{CV} 23 \%$ ) over 9 days in Goat 776 and $418.0 \mathrm{ml} / \mathrm{min}$ (CV 19\%) over 23 days in Goat 851 .

Mean values of uterine blood flow and levels of total lactogenic activity in the uterine vein are given in Table 1. The values are the average of all measurements made during a 24 -h period. The changes in blood flow in the uterine artery of each goat over a $24-\mathrm{h}$ period are shown as mean blood flow per 20 -min period (Text-fig. 1). Blood flow fluctuated over the 24 -h period, markedly so in

Table 1. Total lactogenic activity (TLA, ng sheep prolactin equivalents/ml) in the uterine vein and blood flow in the uterine artery over a $24-\mathrm{h}$ period in pregnant goats

\begin{tabular}{lccccc}
\hline $\begin{array}{l}\text { Goat } \\
\text { No. }\end{array}$ & $\begin{array}{c}\text { No. of } \\
\text { fetuses }\end{array}$ & $\begin{array}{c}\text { TLA* } \\
(\mathrm{ng} / \mathrm{ml})\end{array}$ & $\begin{array}{c}\text { Uterine arterial } \\
\text { blood flow } \\
(\mathrm{ml} / \mathrm{min})\end{array}$ & $\begin{array}{c}\text { Wet weight } \\
\text { of placentomes } \\
(\mathrm{g})\end{array}$ & $\begin{array}{c}\text { Day of } \\
\text { pregnancy at } \\
\text { autopsy }\end{array}$ \\
\hline 123 & 1 & $571 \pm 25$ & $222 \cdot 3 \pm 24 \cdot 5$ & 630 & 120 \\
776 & 1 & $280 \pm 18$ & $181 \cdot 8 \pm 7 \cdot 6$ & 573 & 110 \\
851 & 2 & $491 \pm 16$ & $379 \cdot 3 \pm 20 \cdot 2$ & 920 & 126 \\
\hline
\end{tabular}

* Determined on the same days as blood flow from at least 48 samples over the $24-\mathrm{h}$ period (mean \pm s.e.m.).

$\dagger$ Determined within 3 days of autopsy and calculated as mean \pm s.e.m. of integrated blood flow over 72 consecutive 20 -min periods. 


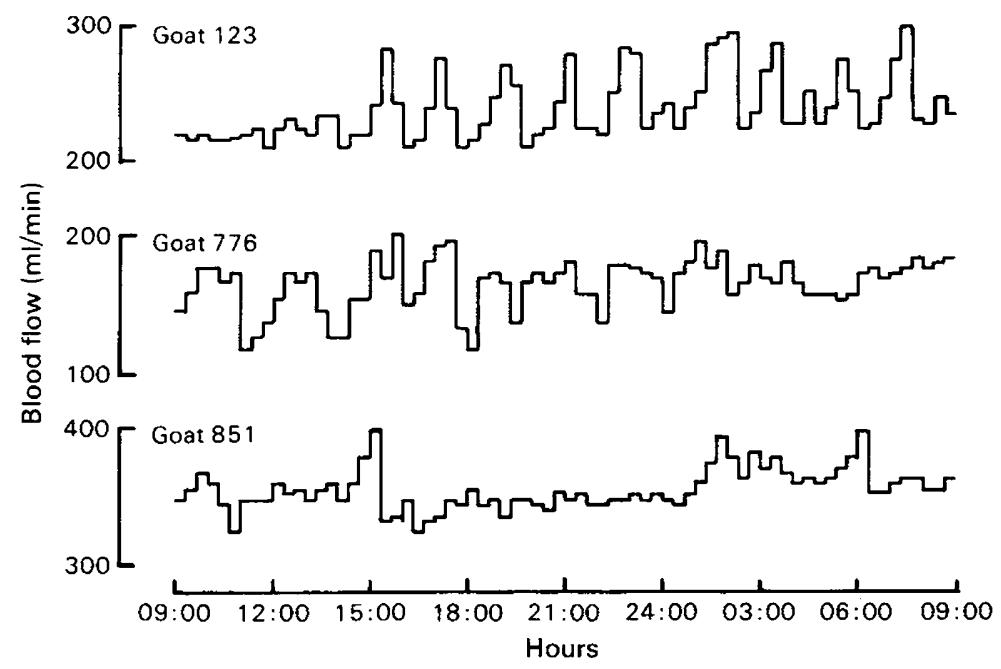

Text-fig. 1. Continuous recording of uterine arterial blood flow over $24 \mathrm{~h}$ in 3 pregnant Saanen goats. Data are presented as mean blood flow for 20-min periods. Lights on 08:00-18:00 h.

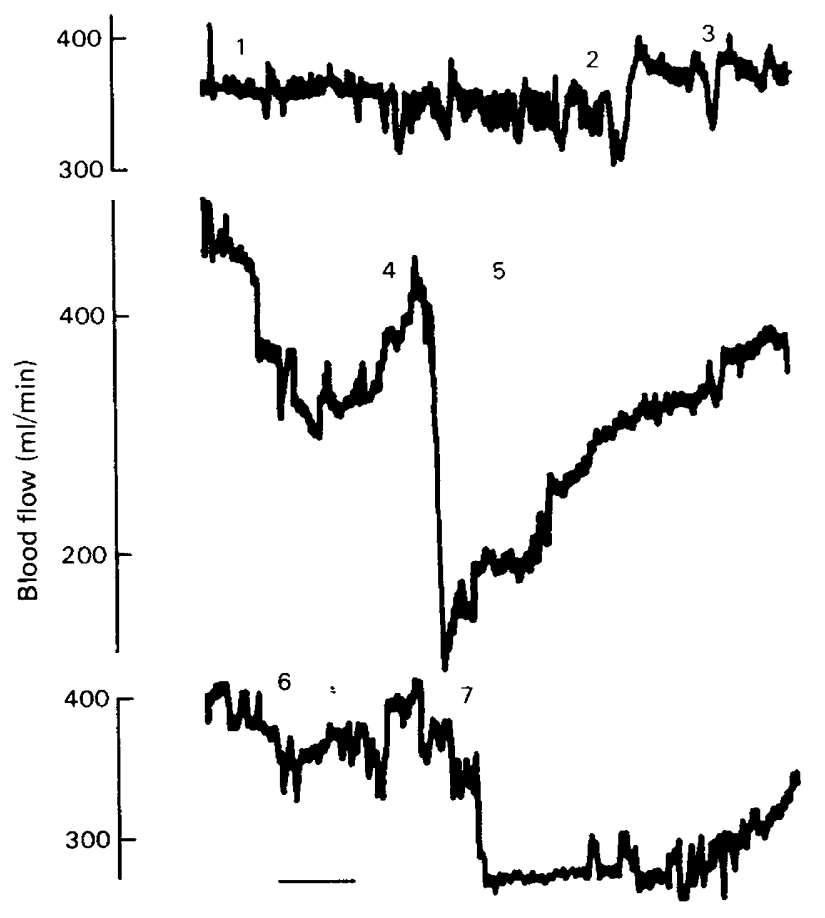

Text-fig. 2. Short-term fluctuations in uterine arterial blood flow in Goat 851. Three separate 8min periods are shown and postural and behavioural changes occurred as follows: 1 , restless, moving about, pawing bedding; 2 , defaecation; 3 , eating hay; 4 , lying down, drowsy, resting head on floor; 5 , lying down, raised head; 6 , eating concentrates; 7 , lay down. The bar indicates $1 \mathrm{~min}$. 
Goat 123 in which the pattern was characterized by slow increases in blood flow followed by rapid decreases to produce a series of peaks occurring at about 90 -min intervals (Text-fig. 1). This pattern was evident in all three 24-h studies performed on this goat (not shown). Fluctuations in the other 2 animals were less regular although a few periods of gradual increase following a rapid decrease could be discerned. In the short-term, blood flow was of ten quite stable, varying by as little as $5 \%$ of the mean for as long as $15 \mathrm{~min}$ (Text-fig. 2). Abrupt changes, usually decreases which were sometimes by as much as $90 \%$, could not be consistently related to postural changes, feeding, defaecation/urination, state of arousal or experimental manipulations (Text-fig. 2).

The spontaneous rhythmic decreases in blood flow in the uterine artery of Goat 123 were accompanied by a decrease to about $35 \%$ in the amplitude of the pulse but only a slight reduction in pulse rate, from 132 to $120 \mathrm{~min}^{-1}$ (Text-fig. 3). By contrast, while adrenaline also produced a $65 \%$ decrease in pulse amplitude the pulse rate was also reduced from 131 to $72 \mathrm{~min}^{-1}$ (Text-fig. 3).

Total lactogenic activity varied in parallel in jugular and uterine venous plasma ( 8 periods, $r=$ $0.88-0.95, n=18-24$ per period, not shown) and was slightly $(5-10 \%)$ higher in the latter. Total lactogenic activity in jugular venous plasma was not related to uterine blood flow. In only 1 of 23 periods thus studied was blood flow correlated with hormone concentrations $(r=0.54$, d.f. $=17, P$ $<0.02$ ). In all other periods, $r<0.32$ (d.f. $=15-22, P>0.1$ ). One period is shown for Goat 123 covering a slow rise and rapid fall in blood flow without parallel changes in total lactogenic activity in jugular venous plasma (Text-fig. 4) and one period for Goat 776 in which the lactogenic activity in uterine and jugular venous blood fluctuate in parallel independently of changes in blood flow (Text-

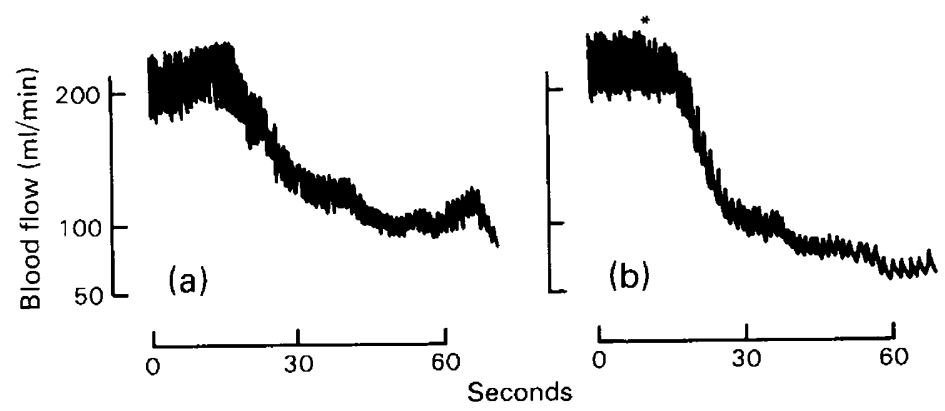

Text-fig. 3. Spontaneous (a) and adrenaline-induced (b) acute changes in uterine arterial blood flow of Goat 123 . * Administration of adrenaline $(1.35 \mu \mathrm{g} / \mathrm{kg}$ body $w \mathrm{t}$ in $2 \mathrm{ml})$ into the jugular vein.

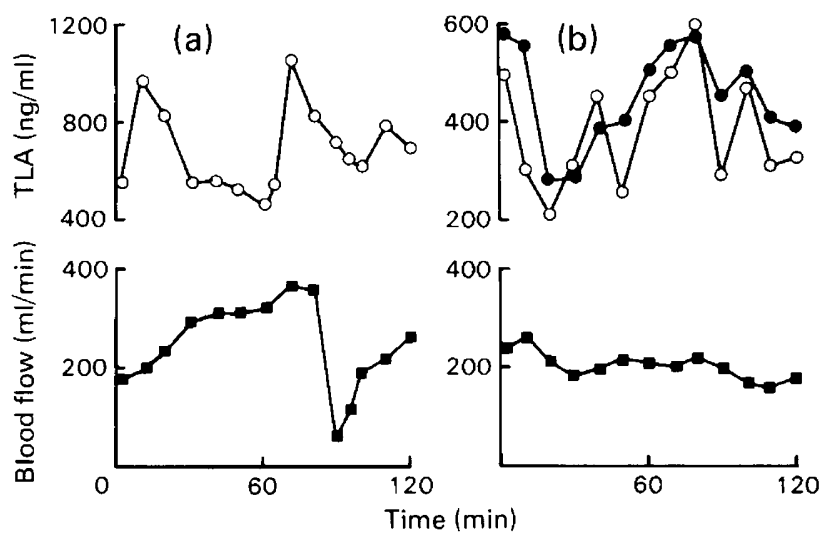

Text-fig. 4. Total lactogenic activity (TLA) and uterine arterial blood flow over a 2 -h period in (a) Goat 123 and (b) Goat 776. TLA in uterine vein; $O-O$ TLA in jugular vein. 
fig. 4). Changes in blood flow produced by adrenaline similarly had no effect on total lactogenic activity in jugular venous plasma (not shown).

\section{Discussion}

In the goats with only a single fetus, blood flow was measured in the uterine artery ipsilateral to the uterine horn containing the fetus. In general blood flow in the ipsilateral artery is greater than in the contralateral artery provided placental attachment is confined to the former. Similarly, in twin pregnancies in sheep the size and extent of placentation in each horn influences the magnitude of blood flow to each (Dilts, Brinkman, Kirschbaum \& Assali, 1969). In the present experiments, therefore, although measurements of blood flow do not represent total uterine blood flow they represent the major component of the blood flow towards the site of production of placental lactogen.

We found no evidence that short-term changes of total lactogenic activity in peripheral plasma were related to blood flow in the uterine artery. However, uterine arterial blood flow in the middle uterine artery may not be a reliable indicator of the degree of perfusion of the intervillous space. In the sheep about $84 \%$ of the uterine flow bathes the cotyledons (Makowski, Meschia, Droegemueller \& Battaglia, 1968). This does not, however, exclude the possibility that changes in cotyledonary perfusion may occur due to redistribution of uterine blood flow while uterine arterial flow is constant or by altered input from the ovarian or posterior uterine arteries. In addition, while fetal and maternal blood flow through the placentome are positively correlated in the sheep, the flow through the placenta is quite variable (Power, Dale \& Nelson, 1981). The most compelling evidence that peripheral concentrations of total lactogenic activity are not related to uterine blood flow comes from Goat 123 in which the total flow regularly dropped by $60-70 \%$ and took up to $120 \mathrm{~min}$ to recover without a change in lactogenic activity. The half-life of caprine placental lactogen is not known but is likely to be $15-60 \mathrm{~min}$ by comparison with clearance rates of related hormones in sheep and goat (Kelly et al., 1974; Handwerger et al., 1977; Bryant, Linzell \& Greenwood, 1970; Bennett \& McMartin, 1979). If a relationship between uterine blood flow and peripheral placental lactogen exists it would be expected to have been evident in Goat 123. But even under conditions where blood flow was depressed for as long as $90 \mathrm{~min}$ no correlated change in total lactogenic activity in the peripheral circulation was found. We therefore conclude that such changes in blood flow do not exert a major effect on release of placental lactogen. The concentration of placental lactogen in the rhesus monkey decreases when the maternal aorta is constricted (Belanger et al., 1971) although the relationship of such a manipulation to normal fluctuations in uterine arterial flow is not clear. In groups of pregnant cows between Days 140 and 245 of gestation the peripheral concentration of oestrone, produced by the gravid uterus, is not simply related to uterine blood flow at the time of sampling (Ferrell \& Ford, 1980). In addition, while average daily progesterone concentrations in peripheral plasma of cyclic cows were correlated with blood flow to the ovary, the diurnal fluctuations of progesterone concentrations could not be correlated with the diurnal changes in ovarian blood flow (Wise, Caton, Thatcher, Barron \& Fields, 1982).

The cause of the spontaneous fluctuations of uterine blood flow in Goat 123 are not known. Various factors reduce uterine blood flow in sheep, e.g. hyperthermia, respiratory alkalosis (Oakes, Walker, Ehrenkranz, Cefalo \& Chez, 1976), severe hypoxia (Dilts et al., 1969), time of day (Walker et al., 1977) and uterine contraction during labour (Greiss, 1965). In non-pregnant sheep, however, myometrial contraction could not be consistently related to transient decreases in uterine blood flow (Fleet \& Heap, 1982). We found no evidence for a circadian variation in uterine blood flow in any goat and the fluctuations in Goat 123 are unexplained.

In addition to short-term fluctuations there are major changes in uterine blood flow related to the stage of gestation. Uterine blood flow in the goat increases markedly between Days 20 and 50 of gestation and then declines by $60-70 \%$ by Day 70 to about $350 \mathrm{ml} / \mathrm{kg} / \mathrm{min}$ which is maintained until 
term (Cotter, Blechner \& Prystowsky, 1969). The peak in blood flows occurs before the normal rise in placental lactogen which takes place about Days 60-70 (Currie et al., 1977; Hayden et al., 1980). Although placental lactogen is related to the number of fetuses in the sheep (Gluckman et al., 1979) and goat (Hayden et al., 1980), factors other than placental mass and blood flow are involved in its control since plasma concentrations of placental lactogen continue to rise (Kelly et al., 1974; Djiane \& Kann, 1975) after cotyledonary growth (Martal \& Djiane, 1977) and uterine blood flow (Greiss \& Anderson, 1970) have reached a plateau.

\section{References}

Belanger, C., Shome, B., Friesen, H. \& Myers, R.E. (1971) Studies of the secretion of monkey placental lactogen. Clin. Invest. 50, 2660-2667.

Bennett, H.P.J. \& McMartin, C. (1979) Peptide hormones and their analogues: distribution, clearance from the circulation, and inactivation in vivo. Pharmac. Rev. 30, 247-292.

Bryant, G.D., Linzell, J.L. \& Greenwood, F.C. (1970) Plasma prolactin in goats measured by radioimmunoassay: the effects of teat stimulation, mating behaviour, stress, fasting and of oxytocin, insulin and glucose injections. Hormones 1, 26-35.

Buttle, H.L., Forsyth, I.A. \& Knaggs, G.S. (1972) Plasma prolactin measured by radioimmunoassay and bioassay in pregnant and lactating goats and the occurrence of a placental lactogen. J. Endocr. 53, 483-491.

Buttle, H.L., Cowie, A.T., Jones, E.A. \& Turvey, A. (1979) Mammary growth during pregnancy in hypophysectomized or bromocriptine-treated goats. J. Endocr. 80, 343-351.

Chan, J.S.D., Robertson, H.A. \& Friesen, H.G. (1978) Maternal and fetal concentrations of ovine placental lactogen measured by radioimmunoassay. Endocrinology 102, 1606-1613.

Chard, T. (1981) Synthesis of placental lactogen by human placentae. In Hormones in Normal and Abnormal Human Tissues, Vol. 1, pp. 409-428. Eds K. Fotherby \& S. B. Pal. Walter de Gruyter, Berlin.

Cotter, J.R., Blechner, J.N. \& Prystowsky, H. (1969) Blood flow and oxygen consumption of pregnant goats. Am. J. Obstet. Gynec. 103, 1098-1101.

Currie, W.B., Kelly, P.A., Friesen, H.G. \& Thorburn, G.D. (1977) Caprine placental lactogen: levels of prolactin-like and growth hormone-like activities in the circulation of pregnant goats determined by radioreceptor assays. $J$. Endocr. 73, 215-226.

Dilts, P.V., Jr, Brinkman, C.R., II I, Kirschbaum, T.H. \& Assali, N.S. (1969) Uterine and systemic hemodynamic interrelationships and their response to hypoxia. Am. J. Obstet. Gynec. 103, 138-157.

Djiane, J. \& Kann, G. (1975) Mise en evidence de l'activité lactogène et mesure dans le serum de l'activité prolactinique du placenta chez la brebis au cours de la gestation. C. r. hebd. Séanc. Acad. Sci., Paris D 280, 2785-2788.

Ferrell, C.L. \& Ford, S.P. (1980) Blood flow, steroid secretion and nutrient uptake of the gravid bovine uterus. J. Anim. Sci. 50, 1113-1121.

Fleet, I.R. \& Heap, R.B. (1982) Uterine blood flow, myometrial activity and their response to adenosine during the peri-implantation period in sheep. $J$. Reprod. Fert. 65, 195-205.

Gluckman, P.D., Kaplan, S.L., Rudolph, A.M. \& Grumbach, M.M. (1979) Hormone ontogeny in the ovine fetus. II. Ovine chorionic somatomammotropin in mid and late gestation in the fetal and maternal circulation. Endocrinology 104, 1828-1833.

Grandis, A.S. \& Handwerger, S. (1983) Differential effects of ornithine on placental lactogen and growth hormone secretion in the pregnant ewe and fetus. $J$. Endocr. 97, 175-178.

Greiss, F.C., Jr (1965) Effect of labor on uterine blood flow. Am. J. Obstet. Gynec. 93, 917-923.

Greiss, F.C., Jr \& Anderson, S.G. (1970) Uterine blood flow during early ovine pregnancy. Am. J. Obstet. Gynec. 106, 30-38.

Handwerger, S., Crenshaw, C., Jr, Maurer, W.F., Barrett, J., Hurley, T.W., Golander, A. \& Fellows, R.E. (1977) Studies on ovine placental lactogen secretion by homologous radioimmunoassay. J. Endocr. 72, 27-34.

Handwerger, S., Crenshaw, M.C., Lansing, A., Golander, A., Hurley, T.W. \& Fellows, R.E. (1978) Stimulation of ovine placental lactogen secretion by arginine infusion. Endocrinology 103, 1752-1758.

Handwerger, S., Grandis, A., Barry, S. \& Crenshaw, M.C. (1981) Stimulation by ornithine of ovine placental lactogen secretion. J. Endocr. 88, 283-288.

Hayden, T.J., Thomas, C.R., Smith, S.V. \& Forsyth, I.A. (1980) Placental lactogen in the goat in relation to stage of gestation, number of fetuses, metabolites, progesterone and time of day. J. Endocr. 86, 279-290.

Kelly, P.A., Robertson, H.A. \& Friesen, H.G. (1974) Temporal pattern of placental lactogen and progesterone secretion in sheep. Nature, Lond. 248, 435437.

Lowe, K.C., Beck, N.F.G., McNaughton, D.C., Gluckman, P.D., Kaplan, S.L., Grumbach, M.M. \& Nathanielsz, P.W. (1979) Effect of long-term bromocriptine infusion on plasma prolactin and ovine chorionic somatomammotropin in the pregnant ewe and fetal sheep. Am. J. Obstet. Gynec. 135, 773-777.

Makowski, E.L., Meschia, G., Droegemueller, W. \& Battaglia, F.C. (1968) Measurement of umbilical arterial blood flow to the sheep placenta and fetus in utero. Circ. Res. 23, 623-631.

Martal, J. \& Djiane, J. (1977) The production of chorionic somatomammotropin in sheep. $J$. Reprod. Fert. 49, 285-289.

Martal, J. \& Lacroix, M.C. (1978) Production of chorionic somatomammotropin (oCS), fetal growth and growth of placenta and corpus luteum in ewes 
treated with 2-bromo-alpha-ergocryptine. Endocrinology 103, 193-199.

Oakes, G.K., Walker, A.M., Ehrenkranz, R.A., Cefalo, R.C. \& Chez, R.A. (1976) Uteroplacental blood flow during hyperthermia with and without respiratory alkalosis. J. appl. Physiol. 41, 197-201.

Parke, L. \& Forsyth, I.A. (1975) Assay of lactogenic hormones using receptors isolated from rabbit liver. Endocr. Res. Commun. 2, 137-149.

Power, G.G., Dale, P.S. \& Nelson, P.S. (1981) Distribution of maternal and fetal blood flow within cotyledons of the sheep placenta. Am. J. Physiol. 241, H486-H496.

Taylor, M.J., Jenkin, G., Robinson, J.S., Thorburn, G.D., Friesen, H. \& Chan, J.S.D. (1980) Concentrations of placental lactogen in chronically catheterized ewes and fetuses in late pregnancy. $J$. Endocr. 85, 27-34.
Vigneri, R., Squatrito, S., Pezzino, V., Cinquerui, E., Proto, S. \& Montoneri, C. (1975) Spontaneous fluctuations of human placental lactogen during normal pregnancy. J. clin. Endocr. Metab. 40, 506509.

Walker, A.M., Oakes, G.K., McLaughtin, M.K., Ehrenkranz, R.A., Alling, D.W. \& Chez, R.A. (1977) 24-hour rhythms in uterine and umbilical blood flows of conscious pregnant sheep. Gynecol. Invest. 8, 288298.

Wise, T.H., Caton, D., Thatcher, W.W., Barron, D.H. \& Fields, M.J. (1982) Ovarian function during the estrous cycle of the cow: ovarian blood flow and progesterone release rate. J. Anim. Sci. 55, 627-637.

Received 14 February 1983 